\title{
In vivo monitoring of Foscan-mediated photodynamic therapy in clinical head and neck procedures using optical spectroscopy
}

\author{
Stephen Kanick, Baris Karakullukcu*, Robert van Veen, Henricus Sterenborg, I Bing Tan, Max Witjes, Arjen Amelink,
} Dominic Robinson

From 2nd Scientific Meeting of the Head and Neck Optical Diagnostics Society

San Francisco, CA, USA. 23-24 January 2010

Photodynamic therapy with $\mathrm{m}$-THPC (Foscan) is as established treatment for superficial squamous cell carcinoma and is also being considered for treatment of larger head and neck tumors. Recently, clinical implementation of Foscan-mediated PDT in the head and neck has not been optimal; a subset of patients has experienced incomplete response. It is well-understood that sufficient quantities of light, drug and oxygen must be present in the targeted tissue in order to deliver sufficient damage. This requirement is complicated by variations in the tissue optical properties and in the photosensitizer uptake rates; however, most clinical protocols do not measure the affect of these factors on the PDT dose delivered to individual patients.

This study represents a first step toward incorporating optical techniques developed to monitor PDT treatments in pre-clinical models into the clinical treatment of head and neck cancer. This clinical study incorporates reflectance and fluorescence spectroscopic measurements are into the PDT-treatment protocol. Spectral analysis allows the extraction of Foscan concentrations and the quantitative determination of tissue physiological parameters that are important to the PDTdelivered dose (e.g. blood volume and hemoglobin saturation). The study identifies the practical and technical challenges of translating these techniques into the clinical setting. Moreover, the data presented here contribute to understanding the link between these optical measurements and the PDT-dose delivered to individual patients during treatment.

Antoni van Leeuwenhoek Hospital, Netherlands Cancer Institute, Amsterdam, The Netherlands
Published: 29 October 2010

doi:10.1186/1758-3284-2-S1-016

Cite this article as: Kanick et al:: In vivo monitoring of Foscan-mediated photodynamic therapy in clinical head and neck procedures using optical spectroscopy. Head \& Neck Oncology 2010 2(Suppl 1):016.
Submit your next manuscript to BioMed Central and take full advantage of:

- Convenient online submission

- Thorough peer review

- No space constraints or color figure charges

- Immediate publication on acceptance

- Inclusion in PubMed, CAS, Scopus and Google Scholar

- Research which is freely available for redistribution

Submit your manuscript at www.biomedcentral.com/submit
C Biomed Central 